\title{
CrimRxiv
}

\section{Repeat and Near Repeat Burglary Victimization in Taiwan}

Tien-Li Kuo, Aiden Sidebottom, Richard Wortley, Tyan-muh Tsai

Published on: Mar 04, 2022

DOI: $10.21428 / c b 6 a b 371.441659 a 7$

License: Creative Commons Attribution 4.0 International License(CC-BY 4.0). 
